\title{
PENINGKATAN KETERAMPILAN BERBICARA MELALUI PENGGUNAAN MODEL EXAMPLE NON EXAMPLE PADA SISWA KELAS V DI SDN 24 TEMMALEBBA KECAMATAN BARA KOTA PALOPO
}

\author{
Mirna Fitriani \\ Institut Agama Islam Negeri Palopo \\ Jl. Agatis Balandai Kota Palopo \\ E-mail:mirna.fitriani53@gmail.com
}

\begin{abstract}
Penelitian ini menggunakan penelitian tindakan kelas. Bertujuan untuk meningkatkan kemampuan berbicara siswa pada proses pembelajaran dengan menggunakan media gambar yang ada pada lingkungan siswa sehingga mudah untuk berbicara. Pelaksanaan penelitian ini dilakukan 2 siklus, setiap sisklus berlangsung selama dua kali pertemuan. Subjek dalam penelitian ini adalah siswa kelas V di SDN 24 Temmalebba Kecamatan Bara Kota Palopo, yang berjumlah 35 siswa terdiri dari 19 orang laki-laki dan 16 orang perempuan. Teknik pengumpulan data yang dilakukan dalam penelitian ini yaitu wawancara, tes dan pengamatan. Penelitian ini dapat menggunakan sebuah teknik analisis data secara kualitatif dan kuantitatif. Data kualitatif kemudian dianalisis menggunakan teknik analisis deskriptif kualitatif, yaitu cara teknik pengolahan data dengan cara mendeskripsikan hasil data kualitatif meliputi hasil observasi dan catatan dilapangan. Sedangkan data kuantitatif dianalisis dengan menggunakan teknik statistik dalam bentuk perhitungan rata-rata (mean). Hasil penelitian ini menunjukkan bahwa nilai rata-rata keterampilan berbicara siswa meningkat pada tiap siklusnya. Pada prasikls yang nilai rata-ratanya 2,13,meningkat pada siklus I yang nilai rata-ratanya 3,04, dan semakin meningkat pada siklus II yang nilai rataratanya 3,77. Kesimpulan dari penelitian ini yaitu dengan menggunaan model example non example maka keterampilan berbicara siswa kelas V di SDN 24 Temmalebba Kec.Bara Kota Palopo dapat meningkat.
\end{abstract}

Keywords: Model Example non Example, Keterampilan Berbicara.

\begin{abstract}
Abstrak
Penelitian ini menggunakan penelitian tindakan kelas. Bertujuan untuk meningkatkan kemampuan berbicara siswa pada proses pembelajaran dengan menggunakan media gambar yang ada pada lingkungan siswa sehingga mudah untuk berbicara. Pelaksanaan penelitian ini dilakukan 2 siklus, setiap sisklus berlangsung selama dua kali pertemuan. Subjek dalam penelitian ini adalah siswa kelas V di SDN 24 Temmalebba Kecamatan Bara Kota Palopo, yang berjumlah 35 siswa terdiri dari 19 orang laki-laki dan 16 orang perempuan. Teknik pengumpulan data yang dilakukan dalam penelitian ini yaitu wawancara, tes dan pengamatan. Penelitian ini dapat menggunakan sebuah teknik analisis data secara kualitatif dan kuantitatif. Data kualitatif kemudian dianalisis menggunakan teknik analisis deskriptif kualitatif, yaitu cara teknik pengolahan data dengan cara mendeskripsikan hasil data kualitatif meliputi hasil observasi dan catatan dilapangan. Sedangkan data kuantitatif dianalisis dengan menggunakan teknik statistik dalam bentuk perhitungan rata-rata (mean). Hasil penelitian ini menunjukkan bahwa nilai rata-rata keterampilan berbicara siswa meningkat pada tiap siklusnya. Pada prasikls yang nilai rata-ratanya 2,13,meningkat pada siklus I yang nilai rata-ratanya 3,04, dan semakin meningkat pada siklus II yang nilai rataratanya 3,77. Kesimpulan dari penelitian ini yaitu dengan menggunaan model example non
\end{abstract}




\section{2 | Mirna Fitriani}

example maka keterampilan berbicara siswa kelas V di SDN 24 Temmalebba Kec.Bara Kota Palopo dapat meningkat.

Kata Kunci,: Model Example non Example, Keterampilan Berbicara.

\section{PENDAHULUAN}

Pendidikan merupakan modal awal manusia untauk terus berkembang di jaman modern saat ini. Menurut Quisumbing "pendidikan sangat memiliki sebuah peran utama dalam mengembangkan sosial dan personal, memengaruhi perkembangan sosial dan individu, kemandirian, tanpa beban, dan kebebasan" (Kunandar 2007: 10). pada pembelajaran untuk mutu pendidikan seperti pembelajaran bahasa Indonesia di sekolah dasar yang bertujuan dalam meningkatkan keterampilan berkomunikasi siswa, baik itu komunikasi secara lisan maupun komunikasi secara tulisan. Keterampilan paling sulit dalam pembelajaran Bahasa Indonesia yaitu berbicara. Dalam berbicara, diperlukan keterampilan khusus karena keterampilan berbicara menuntut seseorang untuk menghasilkan suatu tutur kata bijak yang bermakna. Tidak hanya pada pembelajaran Bahasa Indonesia, tetapi juga pada pembelajaran bahasa lain. Keterampilan berbicara merupakan keterampilan yang tingkat kesulitannya cukup tinggi. Sehingga, guru pun ingin memecahkan persoalan tersebut dengan menerapkan model example non example untuk membantu siswa yang kesulitan ketika ingin berbicara secara langsung.

Berbicara adalah keterampilan seseorang dalam menyampaikan pesan melelui bahasa lisan. Proses berbicara ditujukan kepada orang lain mengakibatkan adanya sebuah kesenjangan dalam informasi (Sunarti \& Subana, 2004: 217). Keterampilan berbicara merupakan suatu keterampilan berbahasa yang diajarkan langsung dan dikuasai siswa tersebut. Hendaknya jika seperti itu, keterampilan berbicara harus bermanfaat untuk dapat meningkatkan mutu komunikasi lisan dengan baik dan normal. Keterampilan berbicara juga menunjang keterampilan seseorang dalam aktivitas berbahasa bahkan berperan penting untuk pembelajaran lainnya sehingga pembelajaran dapat berjalan dengan lancar dan kondusif (Septri Wahyuningrum, \& Retno Winarni, Matsuri, 2015: 1). Keterampilan berbicara sangatlah penting untuk mengajarkan tutur kata yang baik dalam berbicara. 
Berbicara adalah mengungkapkan perasaan, gagasan, menyampaikan sambutan, dialog, pesan dan kesan, bercerita tentang berbagai topik menarik, menceritakan gambar, menceritakan pengalaman pribadi, peristiwa, tokoh, kegemaran, tata tertib, petunjuk, laporan, berekspresi tentang sastra, mendongeng, puisi, syair lagu, berpantun, drama anak (Zulela, 2012: 100). Bahasa adalah sebuah alat komunikasi/interaksi yang sangat penting, orang yang menguasai bahasa dengan baik akan lebih mudah berkomunikasi (Muh. Darisman dan Sumaryati Damyati, 2015: 1). Jadi, berbicara adalah salah satu cara seseorang untuk dapat saling berinteraksi dengan cara bersosialisasi dan beradaptasi dengan lingkungannya sendiri.

Guru di Indonesia harus dapat mendidik secara professional yang memiliki tugas utamanya sebagai mendidik, pembimbing, melatih, dan mampu mengembangkan kurikulum (perangkat berbasis kurikulum), seperti bunyi dalam prinsip "ing ngarso sung tulodho, ing madya mangun karso, tut wuri handayani." Artinya sebagai guru jika berada di depan memberikan suri teladan (gambaran contoh), bila berada di tengah dapat memberikan acuan prakarsa dan di belakang memberikan sebuah motivasi atau dorongan (Rusman, 2014: 15). Guru sangatlah berperan penting dalam memberikan sebuah pengetahuan terhadap siswa sehingga guru akan selalu membimbing dan mendidik. Hal yang demikian ini sebenarnya tidak mengherankan, karena sebenarnya belajar (dan mengajar) adalah tindak pelaksanaan dalam usaha sadar pendidikan (Sumardi Suryabrata, 2010: 3). Hingga memberi umpan balik dan dukungan orang tua juga dapat membantu guru dalam mencerdaskan anak bangsa dengan belajar di rumah.

Karakteristik siswa yang kompleks tersebut menjadikan pijakan dasar untuk menentukan strategi pembelajaran yang akan digunakan. Demikian pula, siswa yang memiliki gaya belajar visual, tentu berbeda penerapan strategi pembelajaran terhadap siswa yang memiliki gaya belajar kinestik. Oleh sebab itu, berperan menjadi guru hendaknya dapat memahami karakteristik siswa yang mengikuti proses pembelajaran (Syamsu, 2015: 70). Seorang guru harus dapat memahami keadaan siswa dan mengetahui kemampuan siswa yang di miliki sehingga tidak membeda-bedakan kemampuan siswa. 


\section{4 | Mirna Fitriani}

Bahasa Indonesia merupakan aspek budaya yang menjadi paling penting dalam komunikasi maupun interaksi lainnya dan menjadi salah satu bahasa Melayu. Bahasa Indonesia diakui sebagai bahasa persatuan yang menjadi peristiwa penting untuk memperjuangankan bangsa Indonesia. Bahasa Indonesia diakui sebagai bahasa persatuan yang menjadi peristiwa penting untuk memperjuangankan bangsa Indonesia (Sukirman Nurdjan, Edhy Rustan, 2010: 8). Bahasa bukan hanya bahasa, adat dan budaya seiring dengan adanya bahasa yang tumbuh secara tradisonal dan untuk berkomunikasi. Pembelajaran bahasa dapat meningkatkan kesadaran diri siswa terhadap nilai-nilai keberadaan dan keberagaman yang melekat pada kehidupan lokal, sebagai faktor yang sangat potensial dalam membangun cara pandang generasi muda yang berwawasan nasionalis di era globalisasi ini (Rustan, 2010).

Pengajar dituntut untuk mampu mengembangankan model pembelajran yang dapat digunakan dalam upaya pencapaian kompeensi pembelajaran. Model merupakan gambaran adanya daya cara pikir pada seseorang. model yang menggambarkan keseluruhan konsep yang saling akan membutuhkan (Benny A. Pribadi, 2009: 86). Diantara model pembelajaran adalah cooperative learning dimana merupakan suatu model pembelajaran dengan menggunakan kelompok kecil, bekerja sama ( Piet A. Sahertian, dan Ida Aleida Sahertian, 1992: 8). Pembelajaran kooperatif mempunyai cara pembelajaran kelompok dimana siswa diminta untuk berkomunikasi dengan lainnya. Dalam hal ini, komunikasi dari sudut pandang makhluk sosial berfungsi dalam merespon keadaan lingkungan yakni sebagai alat untuk menyampaikan pesan dan mengeskpresikan emosi dalam bentuk kata-kata (Rustan \& Subhan, 2018). Cooperative Learning adalah model pembelajaran dimana sistem belajar dan bekerja menggunakan kelompok kecil yang beranggotakan 4-6 individu secara kolaboratif untuk mampu merangsang siswa lebih tertarik untuk belajar (Slavin, 2011: 54). Pembelajaran kooperatif adalah suatu pembelajaran yang dapat membantu siswa untuk saling berkomunikasi memecahkan masalah secara bersama dan saling bertukar pikiran dalam proses belajar.

\section{PiJIES: Pedagogik Journal of Islamic Elementary School}


Cooperative learning mempunyai pengertian sebagai perilaku atau sikap bersama dalam bekerja atau membantu sesama dalam kelompok kerja sama erat yang melibatkan dua orang atau lebih menghasilkan keberhasilan kerja dipengaruhi oleh keterlibatan pada tiap anggota kelompok itu sendiri. Cooperative learning juga dapat diartikan sebagai tugas berstruktur, pembelajaran kooperatif juga dikenal sebagai pembelajaran kelompok (Tukiran Taniredja, 2011: 55). Pembelajaran kooperatif adalah cara belajar sejumlah siswa sebagai anggota kelompok kecil yang tingkatkan kemampuannya berbeda (Mohammad Jauhar 2011:52). Cooperative learning membelajarkan siswa dalam belajar kelompok untuk saling membantu memecahkan masalah bersama yang diberikan.

Cooperative learning suatu pembelajaran yang menarik untuk menciptakan sosialisasi dalam belajar bersama dengan siswa lainnya dilaksanakan menggunakan sharing antara peserta belajar, sehingga mewujudkan pemahaman bersama pada peserta belajar (Rusman, 2013: 202). Cooperative learning juga dapat melibatkan peserta didik untuk aktif belajar dan mengikuti arahan yang diberikan oleh guru. Cooperative Learning lebih diarahkan oleh guru, memberikan tugas, menyiapkan pertanyaan dan menyiapkan bahan informasi untuk dirancang membantu siswa menyelesaikan masalah yang dimaksud menetapkan bentuk ujian pada akhir tugas siswa ( Agus Suprijono, 2009: 54). Tujuan utama dalam penerapan model belajar mengajar cooperative learning adalah siswa mampu belajar secara berkelompok, saling menghargai pendapat satu sama lain dan memberi kesempatan mengungkapkan gagasan dengan menyampaikan pendapat secara berkelompok (Isjoni, 2011: 21). Cooperative learning mengaktifkan cara berpikir siswa untuk selalu mengeluarkan pendapat dari hasil kelompok bersama.

Pembelajaran kooperatif pada siswa untuk pandai mengajar teman mereka yang kurang pandai tanpa merasa dirugikan sama sekali. Siswa yang kurang paham dapat belajar pada suasana yang mengasikkan karena banyak teman yang saling membantu dan memberi motivasi (Made Wena, 2012: 189). Cooperative learning juga diartikan terstruktur dalam tugas bersama pada suasana kebersamaan kepada sesama anggota kelompok lainnya (Tukiran Taniredja dan Evi Miftah Faridli, 2011: 33). Pembelajaran akan efektif jika siswa dapat saling bantu 


\section{6 | Mirna Fitriani}

membantu dengan siswa yang lain untuk bertukar pendapat atau memberikan saran dalam sebuah kelompok.

Pembelajaran akan lebih jelas jika faktor yang lain tetap sama, penghargaan kelompok dan tanggung jawab individual sangat berpengaruh terhadap hasil pencapaian pada pembelajaran kooperatif. Ada beberapa bukti yang menunjukkan bahwa interaksi diantara para siswa kelompok cooperative learning juga dapat menjadi efektif (Robert E. Slavin, 2011: 18). Pembelajaran kooperatif sangat efisien dalam mengajarkan siswa mengenai tanggung jawab bersama yang dapat membantu untuk menumbuhkan rasa simpati dan sosialisasi di dalam kelas.

Pembelajaran bahasa Indonesia memiliki 4 aspek keterampilan seperti keterampilan menulis, membaca, menyimak, dan berbicara, salah satunya ialah aspek berbicara. Berbicara merupakan aspek keterampilan berbahasa yang bersifat produktif dan aktif. Menurut Tarigan berbicara merupakan suatu keterampilan sesorang yang dimliki untuk mengeluarkan suara, bunyi artikulasi ucap atau kata untuk mengekspresikan bahasa, serta menyampaikan pikiran, mengungkapkan gagasan dan perasaan. Hal ini berarti bahwa berbicara merupakan suatu kegiatan atau aktivitas kebahasa, tujuan berbicara adalah untuk berkomunikasi yang digunakan sebagai alat sosial terutama pada jenjang pendidikan (Khundaru Sadhono, Slamet, 2014: 58-59). Jadi keterampilan berbicara merupakan sebagian aspek penting pada interaksi dalam keseharian maupun sosial pada pendidikan.

\section{METODE PENELITIAN}

Penelitian ini yang digunakan adalah penelitian tindakan kelas (PTK) dengan menggunakan model penelitian Tindakan kelas yang diterapkan oleh Kurt Lewin yang terdiri dari empat langkah yaitu: perencanaan, tindakan, observasi, dan refleksi. Pelaksanaan penelitian tindakan adalah proses yang terjadi dalam suatu lingkaran yang terus menerus diawali dengan merasakan datangnya masalah, menyusun perencanaan, melaksanakan tindakan, mengadakan refleksi, melakukan observasi, melakukan perencanaan ulang, melakukan tindakan, dan seterusnya (Wina Sanjaya, 2009: 50). Pendekatan yang akan digunakan dalam pendekatan ini ialah sebuah pendekatan yang akan menerapkan proses interaksi antara siswa satu dan siswa lainnya sehingga akan berpengaruh pada interaksi dalam sosial masyarakat tersebut. Proses pembelajaran yakni belajar dan interaksi mengajar hendaknya lebih PiJIES: Pedagogik Journal of Islamic Elementary School 
mengembangkan keterampilan dan kesanggupan siswa mengadakan hubungan erat dengan orang lain/siswa yang ada pada lingkungan mereka, menunjukkan sikap dan perilaku demokratis, serta menumbuhkan keaktifan dalam kegiatan belajar mengajar pada siswa (Nana Sudjana, 2011: 155). Penelitian ini dilaksanakan di SDN 24 Temmalebba Kecamatan Bara Kota Palopo. Subjek penelitian yang berjumlah 35 siswa yang terdiri atas 19 lakilaki dan 16 perempuan.

Penelitian ini sebagai peneliti lapangan dalam bentuk penelitian tindakan kelas, maka sumber data penelitian, diantaranya a) Siswa merupakan subjek, karena siswa menjadi penentu utama dalam menentukan tidak atau berhasilnya suatu hasil belajar dan juga siswa sebagai objek karena siswa yang akan langsung menerima respons saat pembelajaran berlangsung sehingga saling berinteraksi antara siswa satu dan yang lain. b) guru merupakan bagian aspek komponen dalam menentukan kegiatan belajar mengajar yang mempunyai peran penting untuk menentukan keberhasilan suatu pembelajaran seorang siswa. Teknik yang digunakan untuk mengumpulkan data penelitian ini adalah observasi, wawancara, tes kemampuan berbicara dan pengamatan. Analisis data yang akan dipergunakan dalam penelitian ini adalah analisis data kualitatif dan analisis data kuantitatif. Analisis kualitatif diberlakukan pada data hasil observasi terhadap kegiatan pembelajaran dengan menggunakan model example non example. Sedangkan analisis kuantitatif diberlakukan pada data hasil pemberian tes keterampilan berbicara pada setiap siklus.

\section{HASIL DAN PEMBAHASAN HASIL PENELITIAN}

Penerapan model example non example dalam meningkatkan keterampilan berbicara pada siswa yakni dengan menyiapkan media gambar dimana gambar tersebut diambil berdasarkan kegiatan yang selalu dialami oleh siswa sehingga tidak akan ragu untuk berbicara karena medianya menjadi aktifitas yang selalu dikerjakan dan pada lingkungan keseharian seperti gotong royong, pasar dll. Sehingga melalui gambar siswa akan menyimak, membuat cerita dan menceritakan secara langsung dengan berbicara, dengan cara ini siswa akan diharuskan untuk berbicara karena gambar yang telah disediakan tersebut akan memaksakan siswa untuk berbicara dengan menggunakan bahasa mereka sendiri dengan bantuan bimbingan guru sehingga dengan diterapkannya model example non example dapat meningkatkan keterampilan berbicara pada siswa kelas $\mathrm{V}$. 
Setelah peneliti menerapkan model example non example pada siswa kelas $\mathrm{V}$ dapat diketahui pada keterampilan berbicara siswa selalu meningkat. Hal tersebut dapat diketahui berdasarkan hasil tes keterampilan berbicara yang dilakukan pada setiap akhir pertemuan dari prasiklus, siklus I sampai dengan siklus II. Peningkatan digambarkan dalam bentuk diagram sebagai berikut:

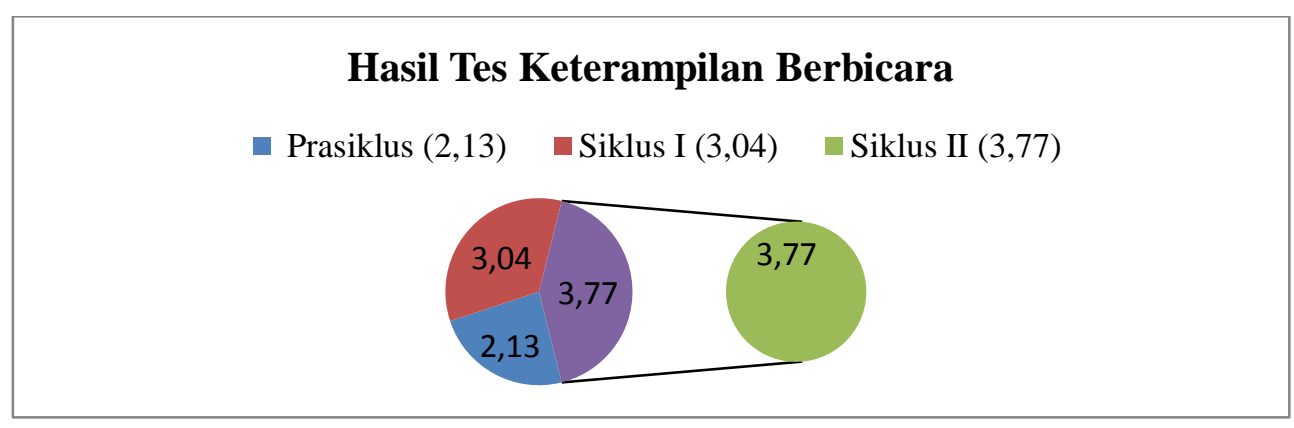

Diagram tersebut menunjukkan bahwa peningkatan keterampilan berbicara pada siswa mengalami peningkatan ditiap siklusnya sehingga mencapai nilai KKM. Penelitian ini memperoleh hasil dengan menggunakan model example non example menunjukkan adanya peningkatan keterampilan berbicara pada siswa kelas V di SDN 24 Temmalebba Kecamatan Bara Kota Palopo.

Pelaksanaan tes keterampilan berbicara prasiklus diketahui bahwa nilai rata-rata dari keseluruhan aspek yang di nilai yaitu 2,13, dimana nilai ratarata lafal 1,85, nilai rata-rata diksi 2,08, nilai rata-rata kefasihan 2,25 , nilai rata-rata sikap 2,28, dan nilai rata-rata kosa kata 2,17. Dari analisis tersebut dapat diketahui bahwa banyak siswa yang mendapat nilai rendah hal ini menunjukkan bahwa banyak siswa yang masih belum menguasai keterampilan berbicara. Pada pelaksanaan tes keterampilan siklus I diketahui bahwa nilai rata-rata dari keseluruhan aspek yang di nilai yaitu 3,04 , dimana nilai rata-rata lafal 2,94, nilai rata-rata diksi 2,82, nilai ratarata kefasihan 2,82, nilai rata-rata sikap 3,57, dan nilai rata-rata kosa kata 3,05. Dari analisis tersebut dapat diketahui bahwa masih banyak siswa yang mendapat nilai rendah hal ini menunjukkan bahwa masih banyak siswa yang belum menguasai keterampilan berbicara. Kemudian, pada pelaksanaan tes keterampilan siklus II diketahui bahwa nilai rata-rata dari keseluruhan aspek yang di nilai yaitu 3,77, dimana nilai rata-rata lafal 3,68, nilai rata-rata diksi 3,51, nilai rata-rata kefasihan 3,71, nilai rata-rata sikap 4,02, dan nilai ratarata sikap 3,94. Dari analisis tersebut diketahui bahwa keterampilan berbicara siswa semakin meningkat, hal ini menunjukkan bahwa keterampilan berbicara siswa dapat ditingkatkan melalui model example non example.

PiJIES: Pedagogik Journal of Islamic Elementary School 


\section{PEMBAHASAN}

Pada Penelitian ini dilakukan sebagai upaya untuk mendapat peningkatan keterampilan berbicara pada siswa kelas V di SDN 24 Temmalebba Kecamatan Bara Kota Palopo dengan menggunakan model example non example. Keterampilan berbicara pada siswa berbeda-beda dan tidak semua dapat tampil memberikan pendapatnya. Sehingga, guru memberi penguatan, kepercayaan diri untuk tampil, dan pemberian hadiah agar lebih berani mengeluarkan pendapatnya melalui berbicara.

Guru memberikan pekerjaan rumah (PR) untuk berlatih berbicara sehingga ketika pembelajaran berlangsung di kelas siswa tidak akan malumalu ataupun ragu untuk berbicara dengan penguatan yang diberikan guru. Penguatan yang diberikan guru dapat menjadi stimulus yang meningkatkan efikasi diri siswa dalam menyelesaikan persoalan yang dihadapi. Efikasi diri siswa yang tinggi dapat mengubah cara pandang siswa mengenai kualitas dirinya sendiri (Thaha \& Rustan, 2017). Belajar adalah suatu perubahan seseorang dari yang tidak baik menjadi pribadi yang baik. Menurut teori behavioristik, belajar merupakan berubahnya pribadi seseorang pada tingkah laku diakibatkan karena adanya interaksi rangsangan stimulus dan perkembangan respons (Asri Budianingsih, 2012: 20). Guru memberikan arahan agar siswa dapat berlatih berbicara agar terlatih dan siap ketika tampil berbicara di depan kelas. Sedangkan Skinner berpendapat bahwa belajar merupakan bagian dari suatu perilaku. Ketika seseorang belajar, maka responsnya menjadi lebih baik. Sebaliknya, bila seseorang tidak melakukan akitivitas belajar maka respons pun akan menurun (Dimiyati Mudjiono, 2006: 09). Pembelajaran akan efektif ketika siswa selalu berlatih untuk belajar sehingga menghasilkan respons umpan balik.

Penerapan model example non example bekerja dalam bentuk kelompok, jika seorang guru menggunakan model ini dapat membantu memberikan peningkatan keterampilan berbicara siswa karena model example non example menginspirasi siswa yang kurang mampu mengungkapkan gagasannya melalui keterampilan berbicara, terjadi interaksi berdiskusi antara siswa, saling toleransi dan menumbuhkan 
kreatifitas siswa. Selanjutnya, model example non example membantu guru dalam pembelajaran untuk memudahkan siswa menerima materi.

\section{PENUTUP}

Berdasarkan uraian hasil penelitian dan pembahasan yang dikemukakan oleh penulis sebelumnya, maka dapat ditarik kesimpulan bahwa dengan menerapkan model example non example dapat meningkatkan keterampilan berbicara siswa, dilihat dari hasil peningkatan antar siklus. Dari prasiklus nilai rata-ratanya 2,13 dan pada siklus I terjadi peningkatan nilai rata-ratanya menjadi 3,04, di siklus II nilai rata-ratanya mencapai 3,77 dan sudah memenuhi KKM atau ketuntasan nilai.

Penerapan model example non example sudah tepat digunakan untuk meningkatkan keterampilan berbicara siswa kelas V di SDN 24 Temmalebba, karena setelah diterapkannya model example non example dapat meningkatkan kreativitas, rasa percaya diri, kecepatan berpikir dan keterlibatan siswa dalam proses belajar. Kemudian menunjukkan perubahan sikap yang positif, meningkat baik dari segi sikap dalam belajar, kehadiran, juga melatih keberaniannya dalam mengutarakan pendapatnya.

Adapun saran yang diberikan dalam penelitian ini: (1) Hendaknya guru dapat melanjutkan penerapan model pembelajaran example non example, sehingga keterampilan berbicara siswa mengalami peningkatan. Selain itu, guru diharapkan mampu menambah variasi belajar yang menarik untuk lebih baik dalam model pembelajaran example non example, agar siswa aktif dalam proses pembelajaran dan menghindarkan agar siswa tidak mengalami kebosanan saat pembelajaran (2) Bagi siswa, siswa perlu berlatih berbicara untuk menambah kata sehingga berkomunikasi dengan lancar, baik, dan benar

\section{DAFTAR PUSTAKA}

Boediono, Koster Wayan. 2001. Statistika dan Probabilitas, Cet I: Bandung: PT Remaja Rosdakarya.

Darisman, Muh, Damyati Sumaryati, 2015. Mudah Belajar Bahasa Indonesia, Bogor: Yudhistira.

Isjoni. 2011. Cooperative Learning Mengembangkan Kemampuan Belajar Berkelompok. Cet V: Bandung: Alpabeta.

Jauhar, Mohammad. 2011. Implementasi Paikem dari Behavioristik sampai Kontuktivistik, Jakarta: Prestasi Pustakarya. 
Kunandar. 2007. Guru Profesional Implementasi Kurikulum Tingkat Satuan Pendidikan (KTSP) dan Sukses dalam Sertifikasi Guru, Jakarta: PT Raja Grafindo Persada.

Muhadjir Noeng. 2002. Metodologi Penelitian Kualitatif. Cet II: Yogyakarta: Rake Sarasin.

Nurjdan, S., Rustan, E. 2010. Kunci Sukses Berbahasa Indonesia. Cet STAIN Palopo.

Pribadi A, Benny. 2009. Model Desain Sistem Pembelajaran. Cet I: Jakarta: Dian Rakyat.

Rusman. 2013. Model-model Pembelajaran Mengembangkan Profesionalisme Guru. Cet IV: Jakarta: Kharisma Putra Utama.

Rusman. 2014. Model-model Pembelajaran. Cet V: Jakarta: PT Raja Grafindo Persada.

Rustan, E. (2010). Pembelajaran Bahasa dan Sastra Daerah Berbasis Multikultural dalam Mewujudkan Pendidikan yang Berkarakter di Era Globalisasi. In Hanna, Firman, \& S. Safitri (Eds.), Kongres Internasional Bahasa-bahasa Daerah Sulawesi Tenggara (pp. 247-249). Baubau.

Rustan, E., \& Subhan. (2018). Komunikasi Verbal Anak Pesisir Usia 7-8 Tahun Pada Transakasi Penjualan Produk Kebudayaan Dengan Turis mancanegara. Jurnal Pendidikan Usia Dini, 12(1), 12-28. https://doi.org/10.21009/JPUD.121 02

Sahertian, Piet dan Sahertian, Aleida, Ida. 2001. Supervisi Pendidikan dalam Rangka Program Inservice Education, Jakarta: PT Rineka Cipta.

Sanddhono, Kundharu dan Slamet. 2014. Pembelajaran Keterampilan Bahasa Indonesia. Cet I: Yogyakarta: Graham Ilmu.

Sanjaya Wina. 2009. Penelitian Tindakan Kelas. Cet I: Jakarta: Kencana.

Slavin. 2011. Model-model Pembelajaran Inovatif. Cet II: Bandung: Alfabeta.

Slavin E Robert. 2011. Cooperative Learning. Cet X: Bandung: Nusa Media.

Subana \& Sunarti. 2004. Strategi Belajar Mengajar Bahasa Indonesia. Bandung: Pustaka Setia.

Sudjana, Nana. 2011. Dasar-dasar Proses Belajar Mengajar. Cet XII: Bandung: Sinar Baru Algensido.

Suprijono, Agus. 2009. Cooperative Learning Teori dan Aplikasi Paikem, Yogyakarta: Bima Bayu Atijah.

Suryabrata, Sumadi. 2010. Psikologi Pendidikan. Ed. 5-17: Jakarta: Rajawali Pers.

Syamsu S. 2015. Strategi Pembelajaran Meningkatkan Kompetensi Guru. Cet I: Makassar: Aksara Timur.

Taniredja, Tukiran dan Faridli, Miftah, Efi. 2011. Model-model Pembelajaran Inovatif. Bandung: Alfabeta. 
Taniredja, Tukiran. 2011. Model-model Pembelajaran Inovatif. Cet II: Bandung: Alfabeta.

Thaha, H., \& Rustan, E. (2017). Orientasi Religiusitas dan Efikasi Diri dalam Hubungannya dengan Kebermaknaan Pendidikan Agama Islam pada Mahasiswa IAIN Palopo. Studi Agama Dan Masyarakat, 13(2), 163-179. https://doi.org/10.23971/jsam.v13i2.551

Wahyuningrum, Septri, \& Winarni Retno, Matsuri. 2017. " Peningkatan Keterampilan Berbicara dengan menggunakan Model Pembelajaran Kooperatif Tipe Time Token", (On Line) http:// jurnal.ftkip.uns.ac.id/index.php/pgsdsolo/ article/view/6243.

Wena, Made. 2012. Strategi Pembelajaran Inovatif Konteporer suatu Tinjauan Konseptual Operasional. Cet VII: Jakarta: Bumi Akasara.

Zulela. 2012. Pembelajaran Bahasa Indonesia. Cet I: Bandung: PT Remaja Rosdakarya. 